\title{
Physiological and developmental responses to temperature by the sea anemone Nematostella vectensis
}

\author{
Adam M. Reitzel ${ }^{1,2,3,4}$, Tim Chu ${ }^{1}$, Sara Edquist ${ }^{1,2}$, Caitlyn Genovese ${ }^{1,2}$, \\ Caitlin Church $^{3}$, Ann M. Tarrant ${ }^{3}$, John R. Finnerty ${ }^{1,2, *}$
}

${ }^{1}$ Department of Biology and ${ }^{2}$ Boston University Marine Program, Boston University, 5 Cummington Street, Boston, Massachusetts 02215, USA

${ }^{3}$ Biology Department, Woods Hole Oceanographic Institution, 45 Water Street, Woods Hole, Massachusetts 02543, USA

${ }^{4}$ Present address: Department of Biology, University of North Carolina at Charlotte, 9201 University City Boulevard, Charlotte, North Carolina 28223, USA

\begin{abstract}
Environmental temperature and an organism's ability to respond to it are critical determinants of the geographic distribution of species. Nematostella vectensis is a burrowing sea anemone that inhabits estuaries along the Atlantic coast of North America from Nova Scotia $\left(45^{\circ} \mathrm{N}\right)$ to Georgia $\left(31^{\circ} \mathrm{N}\right)$. Like other estuarine species, $N$. vectensis is exposed to large daily $\left(>20^{\circ} \mathrm{C}\right)$ and seasonal $\left(>25^{\circ} \mathrm{C}\right)$ fluctuations in temperature, requiring wide temperature tolerances. At the same time, the natural distribution of this species spans a pronounced thermal cline, which may promote the evolution of different temperature optima and tolerances in populations. We tested the thermal tolerance of $N$. vectensis adult and developmental stages, which showed all life cycle stages had critical temperatures within $1^{\circ} \mathrm{C}$ (lethal temperature 39.5 to $40.5^{\circ} \mathrm{C}$ ). When temperature tolerance values were compared with recorded field data, $N$. vectensis is living in environments very close to their physiological limit. We utilized common garden experiments $(13,21$, and $29^{\circ} \mathrm{C}$ ) to test for temperature-specific growth and regeneration rates in $N$. vectensis from different portions of this species' range. Temperature had a significant effect on growth and regeneration rate in all clonal lines, with a significant negative relationship between latitude of origin and growth rate at $29^{\circ} \mathrm{C}$. Individuals from higher latitudes did not exhibit higher growth rates at cooler temperatures. Together, our results show a combination of broad thermal tolerances for developmental and adult stages and evidence for local adaptation to higher temperatures in populations living in lower latitude locations that would be physiologically compromised with future warming.
\end{abstract}

KEY WORDS: Growth rate $\cdot$ Latitude Local adaptation ' Nematostella Regeneration · Temperature tolerance

Resale or republication not permitted without written consent of the publisher

\section{INTRODUCTION}

Temperature is a predominant environmental variable that determines the behavior, physiology, and reproduction of most organisms (Hochachka \& Somero 2002, Pörtner 2002, Parmesan 2006). Environ- mental temperatures directly influence most biochemical processes and thereby exert a strong impact on the survival and distribution of species, particularly thermoconformers (Somero 2012). The clear consensus among climatic models is that temperatures will steadily increase in the coming decades, 
leading to higher average annual temperature as well as increases in seasonal fluctuations (Solomon et al. 2007, Lima \& Wethey 2012). Therefore, increasing global temperatures are predicted to significantly shift species ranges, where poleward migration is possible, and promote extinctions of more temperature sensitive species (Pörtner et al. 2001, Helmuth et al. 2002, Harley et al. 2006). Climate change presents a particular challenge for organisms living in 'island' habitats, be they actual islands (Carpenter et al. 2008), mountain tops (McDonald \& Brown 1992), or isolated bodies of water (Xenopoulos et al. 2005). Organisms living in such isolated locations confront significant barriers to migration, and therefore must either exhibit strongly plastic physiology, genetically adapt to the shifting environment, or undergo local extinctions (Parmesan 2006, Visser 2008).

Several studies using coastal species have provided evidence for shifts in distribution due to changing local temperatures (Harley et al. 2006, Doney et al. 2012). Additionally, experimental evidence for both adults and larvae has indicated a relationship between latitude and temperature tolerance for a number of marine species (Vernberg 1962, Stillman \& Somero 2000, Jansen et al. 2007 , Zippay \& Hofmann 2010), which, in many cases, differs from terrestrial species (Sunday et al. 2011). In many reported cases, the temperature tolerance for individuals from a particular location may be near the local temperature maximum, which may explain the strongly correlated observed shifts in distribution reported from field studies (Jentsch et al. 2007, Tomanek 2008).

The responses of a particular species to environmental temperature is likely to be multifaceted, with the temperature optima and temperature sensitivity of life cycle stages, physiological processes, and environmental interactions (e.g. with competitors or anthropogenic stressors) all serving as contributing factors to the overall organismal response (Hoffmann \& Sgro 2011, Magness et al. 2011, Ruff et al. 2011). As these factors may combine in unpredictable ways to determine an organism's response to temperature, and as the interaction of these variables may differ between populations, studies that measure a variety of response variables (e.g. lethal temperature maxima at multiple life stages, growth rates, physiological performance) are particularly informative. Also, the shape of these responses in multiple populations of a particular species will be needed to characterize organismal response to environmental variation, including temperature (Schulte et al. 2011). Such studies will provide a more comprehensive understand- ing of how a particular species has adapted to local temperatures and how it may respond to future changes in the climate.

Estuaries are productive habitats that are crucial to the survival of many species including estuarine specialists as well as transient species for which estuaries provide nursery grounds or seasonally important food sources (Pennings \& Bertness 2001). This latter group includes commercially important fishes and shellfishes and endangered shore birds (Kennish 2002). In the near term, estuarine species experiencing the most pronounced effects of global climate change are likely to be estuarine specialists, particularly those with limited mobility. Because these organisms are specifically adapted to the brackish water, they are poorly adapted to the surrounding fresh water and marine environments. From the perspective of these organisms, estuaries are essentially islands (Bilton et al. 2002), and if their mobility is limited, they may be unable to migrate to new locations to escape increasing temperatures.

Comparisons of thermoperformance by individuals collected from populations throughout their range reveal the response and potential for adaptation to changing temperatures. Such comparisons allow determination of whether temperature adaptation has previously occurred and may therefore occur again. One well-established estuarine model for studying temperature adaptation is the common killifish Fundulus heteroclitus, which ranges over a dramatic thermocline from Nova Scotia to Florida. Studies have shown that southern killifish exhibit significantly higher critical thermal maxima, while northern killifish exhibit significantly lower critical thermal minima (Fangue et al. 2006, Schulte et al. 2011). These differences in organismal performance have been linked to differences in the activities of key glycolytic enzymes and the transcription of the underlying genes (Crawford \& Powers 1989, Powers et al. 1991). The clear evidence of temperature adaptation in the common killifish suggests that other estuarine species with wide geographic distributions may harbor similar adaptations.

The starlet sea anemone Nematostella vectensis is an infaunal estuarine species that is well positioned to characterize responses to environmental temperature and to test for potential adaptation. The geographic range of $N$. vectensis includes most of the Atlantic and Pacific coasts of North America and southeast England (Hand \& Uhlinger 1994, Reitzel et al. 2008a). Cnidarians occupying a similar geographic range have been used as experimental models of temperature adaptation and acclimation for 
nearly a century, e.g. anemones (Shick et al. 1979, Shick 1991), or jellyfish (Mayer 1914, Arai 1997). More recently, reef-building corals have been used as experimental models to quantify the genetic components that underlie variation in temperature responses (Meyer et al. 2009, Császár et al. 2010), providing insight into the adaptability of natural populations. $N$. vectensis is a useful and complementary cnidarian model system for investigating temperature adaptation for several reasons.

(1) Nematostella vectensis encounters dramatic daily and seasonal variation in temperature as a result of inhabiting shallow and ephemeral salt marsh pools. These pools are rapidly warmed by solar radiation, and they may be rapidly cooled by tidal or riverine inputs that may be regular or highly sporadic. Such short-term temporal variability in temperature would tend to promote wide thermal tolerances in all populations, regardless of their location.

(2) The natural range of Nematostella vectensis extends over a dramatic latitudinal temperature cline along the Atlantic coast of North America. This species has been reported from Kingsport, Nova Scotia $\left(45^{\circ} \mathrm{N}\right)$ to Sapelo Island, Georgia $\left(31^{\circ} \mathrm{N}\right)$. Such differences between the mean annual temperatures in different estuaries would tend to promote local adaptation, particularly in the absence of extensive gene flow between populations (Warner 1997, Kawecki \& Ebert 2004, Garant et al. 2007).

(3) Recent genetic analysis suggests that gene flow between estuaries is quite limited. Population genetic structure from populations throughout Nematostella vectensis' range has revealed a striking degree of genetic structure between populations and even subpopulations in a single marsh (Darling et al. 2004, Reitzel et al. 2008a, Darling et al. 2009), which suggests very low levels of gene flow. Such genetic structuring will tend to promote the evolution of local adaptation.

(4) Nematostella vectensis is ideal for laboratory studies to test temperature responses over development and to assess potential genotype-by-environment interactions. Large numbers of anemones can be cultured in small bowls of non-circulating, artificial sea water (Hand \& Uhlinger 1992, 1995). Under laboratory conditions, $N$. vectensis will undergo sexual reproduction regularly and all developmental stages can be cultured. Also, like many aquatic invertebrates, the animal's ability to regenerate rapidly facilitates the production of clonal lines, such that genetically identical individuals can be used in experiments to discern genetic effects and genotypeby-environment interactions as done previously for other cnidarians (Shick et al. 1979, Shick \& Dowse 1985, Zamer et al. 1999).

(5) Nematostella vectensis is a useful experimental model for understanding the thermal responses of estuarine species as its morphological organization is simple. Sea anemones are composed of only 2 tissue layers, and lack any organ systems or compartmentalization, besides an inner body space. Previous studies in various coastal invertebrates and fishes have shown that particular organ systems, predominantly the cardiovascular system, are sensitive to temperature and may underlie acclimatization and local adaptation (Stillman \& Somero 1996, Pörtner 2002, Braby \& Somero 2006, Somero 2011). By lacking such specialized organ systems, sea anemones, and other organisms with similarly simple organization, may provide insight into more fundamental (cellular, molecular) aspects of physiological limits.

Here, we report results from a suite of experiments to test the thermosensitivity of life cycle stages and characterize growth and regeneration rates of individuals from Nematostella vectensis populations cultured in temperatures typical of the northern and southern portions of their range. Our objectives were to determine: (1) whether certain stages of the life cycle were particularly sensitive to thermal extremes and how thermosensitivity relates to environmental temperatures measured by field monitoring; (2) whether growth rates measured in common garden experiments provided evidence for local adaptation to temperature; and (3) whether the regeneration rate of adults was related to environmental temperature and geographic origin. Together, our results suggest that developmental stages are remarkably tolerant to high temperature, but that this species is living near its thermal maxima. We also show extensive variation in growth rates, but not regeneration rate, from individuals collected throughout the natural range, and the variation in growth rate at $29^{\circ} \mathrm{C}$ was significantly correlated with latitude of origin a signature of adaptation to warm temperatures.

\section{MATERIALS AND METHODS}

\section{Collection}

Adult Nematostella vectensis were collected throughout the species' reported range (Table 1, Hand \& Uhlinger 1994, Reitzel et al. 2008a). For collection, sediment from salt marsh pools was sieved through a $1 \mathrm{~mm}$ mesh. Adults were isolated, placed in fresh artificial seawater at the standard culturing 
Table 1. Nematostella vectensis. Geographic site name and latitude for populations sampled in this study

\begin{tabular}{|lc|}
\hline Location & Latitude $\left({ }^{\circ} \mathrm{N}\right)$ \\
\hline Baruch, South Carolina (SC), USA & 33.19 \\
Rhode River, Maryland (MD), USA & 38.89 \\
Meadowlands, New Jersey (NJ), USA & 40.81 \\
Sippewissett, Massachusetts (MA), USA & 41.35 \\
Pocasset, Massachusetts (MA), USA & 41.43 \\
Neponset, Massachusetts (MA), USA & 42.16 \\
Spurwink, Maine (ME), USA & 43.59 \\
Kingsport, Nova Scotia (NS), Canada & 45.09 \\
\hline
\end{tabular}

salinity for $N$. vectensis (12\%) and transported to the laboratory for culturing. Adults were then placed in larger containers $(500 \mathrm{ml})$ and fed freshly hatched Artemia spp. 2 or 3 times per wk.

\section{Field temperature}

(1) To quantify the daily temperature dynamics of high marsh habitat, we characterized the temperature dynamics of a tidal pool at Great Sippewissett Marsh, Massachusetts, USA. Temperature data were collected every 15 min over a 6 mo period (May 1 to November 1, 2008) by a HOBO Pendant Temperature Logger (Onset Computer Corporation). Loggers were fastened to thin plastic pipes and positioned just above the sediment layer to approximate the temperature that the epibenthic Nematostella vectensis would experience. (2) To characterize the latitudinal trends in temperature, we compared monthly average and high air temperatures over a $30 \mathrm{yr}$ period (1980-2010) for 5 locations spanning the Atlantic coast of North America (Georgetown, South Carolina; Royal Oak, Maryland; Meadowlands, New Jersey; Boston, Massachusetts; Eastport, Maine). As temperature data from estuaries were not available, we utilized these air temperature data (collected from the National Weather Service for each of the locales listed above) to approximate field temperatures. Air temperatures can fall below the temperature at which water freezes, so we corrected the low temperature data to reflect the freezing temperature of water with a salinity of 35 (approx. $-2^{\circ} \mathrm{C}$ ). Waters in estuarine environments fluctuate widely and are dependent on the precise salinity, so the exact freezing temperature could deviate from this prescribed minimum temperature. To get an assessment of the relationship of air and water tempera- ture, we regressed mean monthly air temperature from the National Weather Service and water temperature data collected by the field-deployed temperature logger at Great Sippewissett Marsh, Massachusetts. The regression showed a strong, linear relationship (air temperature $=0.68 \times$ water temperature $+1.99, R^{2}=0.96$ ), suggesting air temperature data are representative but not exact measures of water temperature data in these high marsh environments. Whether a similar relationship between air and water temperature occurs at other locations is unknown due to a lack of data from high marsh estuarine habitats.

\section{Thermal tolerance of developmental stages}

Nematostella vectensis reproduces weekly in the laboratory. Female anemones release eggs in a gelatinous mass which are externally fertilized by males. Within the gelatinous egg mass, fertilized eggs develop to early embryos. Subsequently, early larvae swim from the degraded egg jelly, develop into an elongated late larval stage, and then settle as a 4-tentacle juvenile. We compared temperature tolerance of the embryos, early larvae, late larvae, and juveniles by calculating the temperature at which $50 \%$ of individuals die (lethal temperature, $\mathrm{LT}_{50}$ ) using the temperature gradient feature of a MyCycler thermal cycler (Bio-Rad Laboratories). To obtain fertilized eggs, males and females were cultured in glass dishes and spawned under standard culturing conditions. Because the developing embryos are normally retained within the egg mass, we dissolved the egg jelly with a $2 \%$ cysteines wash to isolate individual embryos at the blastula stage ( 12 h post fertilization) for experimentation. To measure temperature tolerance, individuals at each developmental stage were pipetted into a 96well plate that was then fitted with a rubber mat to prevent evaporation during the temperature exposures. Individuals in the plate were rapidly transitioned from their standard culture temperature $\left(21^{\circ} \mathrm{C}\right)$ to 1 of 8 elevated temperatures using the thermal cycler's gradient feature: 37.0, 37.3, 38.0, $39.1,40.5,41.7,42.4$, and $43.0^{\circ} \mathrm{C}$. Exposure to elevated temperatures lasted for $0.5 \mathrm{~h}$. Survival was assessed $24 \mathrm{~h}$ later by observation through a dissecting microscope (Olympus ZX-10). For each trial, 12 ind. from a particular stage were assayed per temperature and each trial was replicated 4 times. We also exposed adults to elevated temperatures using 6 standard incubators set at $1^{\circ}$ incre- 
ments from 40 to $45^{\circ} \mathrm{C}$, spanning a temperature range determined by pilot experiments. Four replicates of 10 adults each were placed in Petri dishes and incubated at each temperature for $0.5 \mathrm{~h}$. Following the exposure, we determined percent survival in each replicate after returning the culture dishes to room temperature for $24 \mathrm{~h}$. Individuals were categorized as live or dead by visual inspection, where dead individuals had disintegrated or lacked response to physical stimulus with a pipette tip. As populations in the field experience elevated temperatures for variable amounts of time, we exposed $N$. vectensis juveniles to the 8 elevated temperatures for 4 exposure durations $(0.5,1.0,1.5$, and $6.0 \mathrm{~h}$ ). Experiments were conducted using juveniles resulting from sexual reproduction by adults collected from Sippewissett Marsh, Massachusetts that had settled as 4-tentacle polyps within the previous $7 \mathrm{~d}$. As in the previous experiments, survival was determined $24 \mathrm{~h}$ after the experiment by visual inspection. $\mathrm{LT}_{50}$ values for all experiments were calculated for each treatment with Graphpad Prism (version 5) using nonlinear, least squares regression ( $\log \mathrm{IC} 50)$. The mean $\mathrm{LT}_{50}$ values for life cycle stages and exposure times were compared using ANOVA with Tukey-Kramer post hoc comparisons (JMP, version 5.0.1).

\section{Thermal tolerance of juveniles from different estuaries}

We were successful in spawning populations of individuals collected from 3 geographic locations: Sippewissett, Massachusetts; Rhode River, Maryland; and Baruch, South Carolina. Attempts to procure fertilized eggs from other populations were unsuccessful, primarily due to a lack of males collected from these locations. Multiple, fertilized egg masses were collected from each spawning population, transferred to clean water, and observed for development to the juvenile stage. Juveniles from each population were individually pipetted into 96well plates and subjected to the identical temperature gradient profile as described above. We calculated $\mathrm{LT}_{50}$ values for juveniles from each population (12 ind. per treatment, 4 replicate experiments) using the same methods described in the previous section. We measured $\mathrm{LT}_{50}$ for 2 temperature durations, 0.5 and $6.0 \mathrm{~h}$, because earlier results with juveniles from one population (Sippewissett, Massachusetts) showed that these durations yielded significantly different within-population $\mathrm{LT}_{50}$ values.

\section{Establishment of clonal lines for common garden experiments}

Randomly selected adults were isolated from specimens originally collected at each focal population and segregated into individual containers $(500 \mathrm{ml})$ to serve as the founders for clone lines. These individuals were cultured under the same conditions as the general population. The clonal founders were bisected through the middle of the column with a scalpel, and the resulting oral and aboral fragments were allowed to regenerate. This process was repeated until the population of each clonal line exceeded 50 ind.

Clonal founders were chosen based on sex and geographic distribution. Females were selected to permit subsequent monitoring of egg production. With respect to geographic origin, we focused on populations from the Atlantic coast of North America spanning the coastline from Nova Scotia to South Carolina. This represents the most pronounced latitudinal thermal gradient from the species' known range, and it represents the presumed native range of the species (Reitzel et al. 2008a). Individuals from these clonal lines were utilized in 2 common garden experiments to measure the effects of temperature on growth and regeneration rate.

\section{Growth rate}

Before commencing the experiments, all adults were cultured individually in containers of $100 \mathrm{ml}$ artificial seawater for $1 \mathrm{wk}$ at the experimental treatment temperature $\left(13,21\right.$, or $\left.29^{\circ} \mathrm{C}\right)$. The experiment comprised 12 clone lines from 8 different estuaries. For each clone line, 5 ind. were subjected to each of 3 constant temperatures: 13,21 , and $29^{\circ} \mathrm{C}$. These values are well within the range of temperatures typically encountered by this species in its natural environment, and preliminary experiments showed that the individuals remained active at all 3 temperatures. Individuals were fed 3 times per week with freshly hatched brine shrimp larvae (Artemia spp). The amount of food was standardized across treatments: at each feeding, each anemone received $1 \mathrm{ml}$ of a culture of freshly hatched Artemia that was prepared by adding $1 \mathrm{~g}$ of Artemia cysts to $100 \mathrm{ml}$ of artificial sea water at 30 salinity. The Artemia culture was swirled before dispensing each aliquot of food in order to disperse the larvae evenly. The sea anemones were given $6 \mathrm{~h}$ to feed, after which time the water in the experimental chambers was replaced with fresh 
artificial sea water (salinity 12) that had been equilibrated to the appropriate treatment temperature. This quantity of Artemia was well in excess for what could be consumed in this time period resulting in an ad libitum feeding treatment. Before each feeding, the treatment chambers were checked for egg masses or aboral fragments, which are generated by physal pinching (Reitzel et al. 2007). We did not observe any egg laying or fission during the course of these experiments.

The size of individual anemones was measured at the beginning of the experiment and after $4 \mathrm{wk}$. Size was quantified by measuring digital photographs of individual anemones overlain above a $1 \mathrm{~mm}$ grid, which served as an individual calibration for later measurements (described below). The individuals were given time to assume a relaxed feeding posture (as evidenced by extended tentacles and the absence of circumferential folds in the column wall), and they were photographed from the side with a digital cam- era (Nikon CoolPix) attached to a dissecting microscope (Olympus ZX-10). In preliminary analyses, we quantified both column length and the 2-dimensional projection of column surface area using ImageJ software (NIH). To measure length, we determined the aggregate length of a series of short line segments that closely tracked the midpoint of the column from the tip of the foot (or physa) to the tip of the mouth. To measure area, we outlined the entire column from oral opening (excluding the tentacles) to the physa and calculated the area of this irregular shape. Repeated measures from the same individual showed that column area was a more consistent size measurement, so this measurement was used to calculate growth rate. The total change in column area $(A)$ was calculated as $A_{\text {final }}-A_{\text {initial }}$ and is presented as growth rate per week.

Linear regression was used to test for significant relationships between initial column size and final column size in the growth rate experiment. To deter-
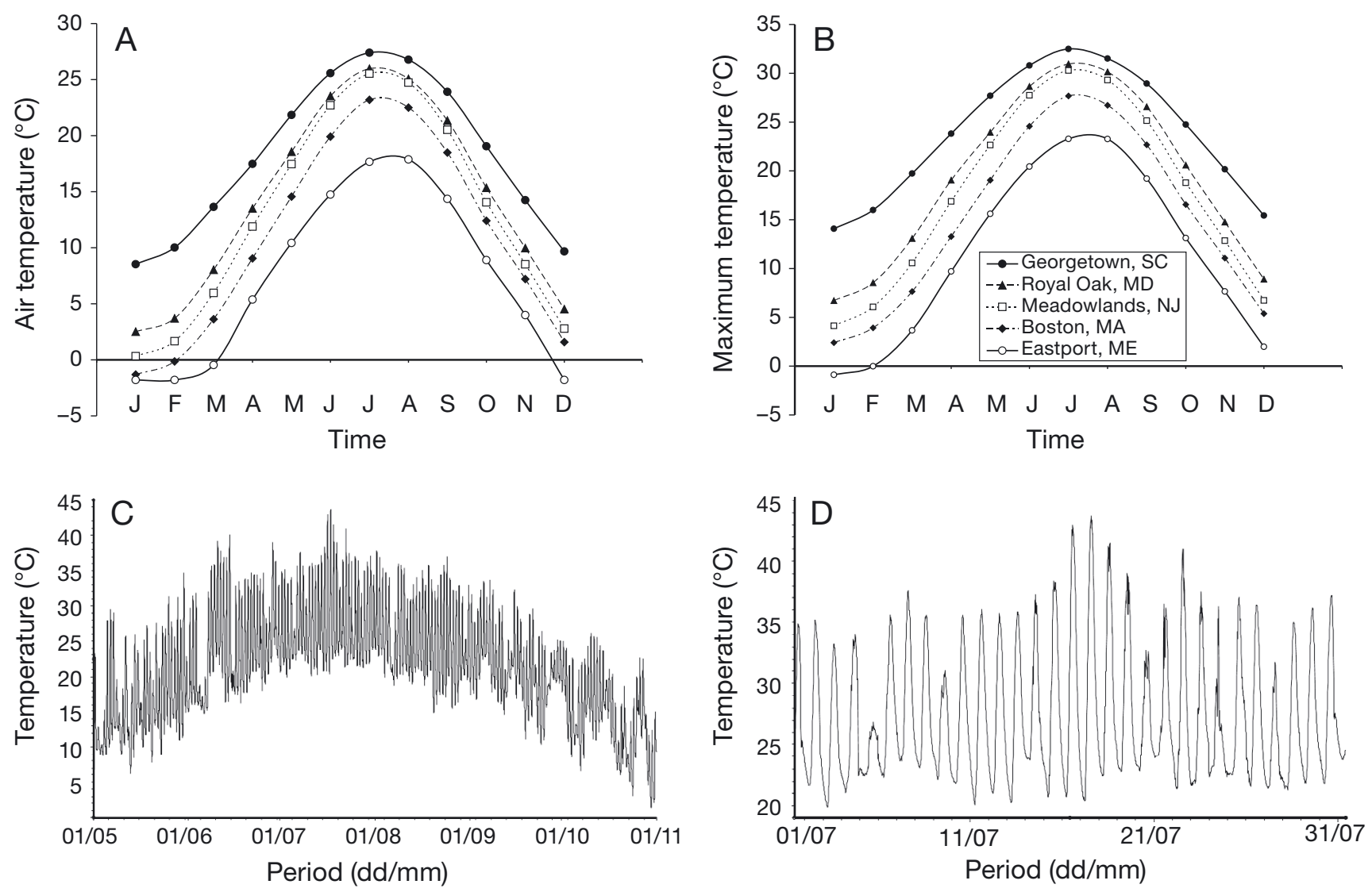

Fig. 1. Nematostella vectensis. Broad scale and local temperature dynamics of environments serving as habitat. (A) Air temperatures (monthly means) from 5 locations along the Atlantic coast of North America indicating the pronounced thermocline along this geographic range. (B) Maximum temperatures (monthly means) for the same sites as in (A). (C) Field data collected in 2008 by a temperature logger positioned in a pool occupied by $N$. vectensis at Great Sippewissett Marsh, Massachusetts. Data were collected every 15 min over a 6 mo period and show the large daily and seasonal variation in high marsh tidal pools. (D) Magnification of temperature data in in (C) showing the warmest period of the field data collected in 2008 
mine the effect of multiple predictor variables (initial size, temperature, population, temperature $\times$ population) on the response variables (growth rate), we used standard least squares multiple regression (JMP). The significance of predictor variables was assessed with the residual maximum likelihood (REML) method effects tests as implemented in JMP to produced unbiased estimates of variance and covariance components. Two-way ANOVAs with Tukey-Kramer post hoc tests were used to test for significant differences in growth rate of the column between temperatures for individual clonal lines generated from the same source population. Finally, linear regression was used to analyze the relationship between growth rate and latitude of origin in each individual temperature treatment.

\section{Regeneration rate}

The effect of temperature on regeneration was evaluated by bisecting individuals transversely through the midpoint of the column using a razor blade and then measuring the success and rate of regeneration at 13,21 , or $29^{\circ} \mathrm{C}$. From each of 5 different clone lines, which span the sampled thermocline, 10 ind. were subjected to this treatment (Kingsport, Nova Scotia; Neponset, Massachusetts; Sippewissett, Massachusetts; Meadowlands, New Jersey; Baruch, South Carolina). The use of clonal lines results in each geographic location being represented by a single genotype. Following bisection, the aboral fragment of each individual was isolated into a glass bowl containing $50 \mathrm{ml}$ of artificial seawater (salinity 12) maintained at one of the temperatures. Before bisection, each individual's size (2-dimensional column area) was measured as described above to account for potential size effects of the adult as well as the excised portion on regeneration. The regeneration of the aboral fragment was measured and monitored daily for a period of $14 \mathrm{~d}$. Each day, the regenerating polyps were photographed against a $1 \mathrm{~mm}^{2}$ grid to standardize the measurements. The presence and number of tentacles were counted by examining live individuals through the dissecting microscope. Tentacle development was monitored for at least $6 \mathrm{~d}$ subsequent to the initial appearance of tentacles.

To determine the effect of multiple predictor variables (initial size, adult size before bisection, temperature, population, and temperature $\times$ population) on the 2 response variables (time to regeneration and regeneration rate), we used standard least squares fitting multiple regressions (JMP). The significance of predictor variables was assessed with the residual maximum likelihood (REML) method effects tests as implemented in JMP. Additionally, we statistically compared the rate of tentacle growth among individuals at each time point using 2-way ANOVA with Tukey-Kramer post hoc comparisons.

\section{RESULTS}

\section{Field temperature}

Comparisons of mean monthly temperatures from 5 locations along the Atlantic coast of North America quantified the latitudinal temperature pattern along this geographic transect (Fig. 1A). The lowest latitude site located in South Carolina was on average $10^{\circ} \mathrm{C}$ warmer than the highest latitude location in Maine during summer months. The temperature difference was even larger in the winter months with a difference of $\sim 15^{\circ} \mathrm{C}$ between South Carolina and Maine. The correspondence between air and water temperatures over $6 \mathrm{mo}$, for which we collected data from 1 isolated pool (see below), was high $\left(R^{2}=0.96\right)$ with water temperatures being on average $3^{\circ} \mathrm{C}$ higher. We also surveyed mean maximum temperatures for these same 5 locations (Fig. 1B). The patterns for the high temperatures were similar to the average temperatures (differing by 1 to $5^{\circ} \mathrm{C}$ ), except the Maine location, which was $\sim 8$ to $10^{\circ} \mathrm{C}$ cooler in the summer months.

Mean temperature summaries do not capture the large fluctuations in daily temperatures experienced by organisms living in high marsh aquatic environments, so we used field temperatures for a high marsh tidal pool occupied by Nematostella vectensis at Great Sippewissett Marsh, Massachusetts. Over a 6 mo period (May 1 to November 1, 2008), temperatures varied from a low of $1.3^{\circ} \mathrm{C}$ at the end of October to $43.7^{\circ} \mathrm{C}$ in mid July (Fig. 1C). Within a single day, temperatures within these tidally restricted pools varied by as much as $20^{\circ} \mathrm{C}$ (Fig. 1D).

\section{Thermal tolerance of developmental stages}

Nematostella vectensis embryos, early larvae, late larvae, and juveniles had $100 \%$, or near $100 \%$, survival in temperatures up to $39^{\circ} \mathrm{C}$. However, survival decreased to near $0 \%$ at $41^{\circ} \mathrm{C}$ for most trials, indicating a very sharp thermal window separating tolerable temperatures. There was a significant difference in $\mathrm{LT}_{50}$ over all developmental stages $\left(F_{3,11}=11.6, \mathrm{p}=\right.$ 
0.003). In post hoc comparisons, the calculated $\mathrm{LT}_{50}$ for embryos and the 2 larval stages were statistically indistinguishable (Fig. 2A). The juvenile stage had a statistically higher $\mathrm{LT}_{50}$ that differed from the earlier development stages by $<1^{\circ} \mathrm{C}$.

Temperature duration showed a significant effect on $\mathrm{LT}_{50}$ of juveniles $\left(F_{3,11}=17.0, \mathrm{p}<0.001\right)$. Calculated $\mathrm{LT}_{50}$ values were not significantly different for durations of $0.5,1.0$, and $1.5 \mathrm{~h}$ (Fig. 2B). However, juveniles exposed at temperature for $6 \mathrm{~h}$ had a significant decrease in lethal temperature $\left(\sim 2^{\circ} \mathrm{C}\right)$.

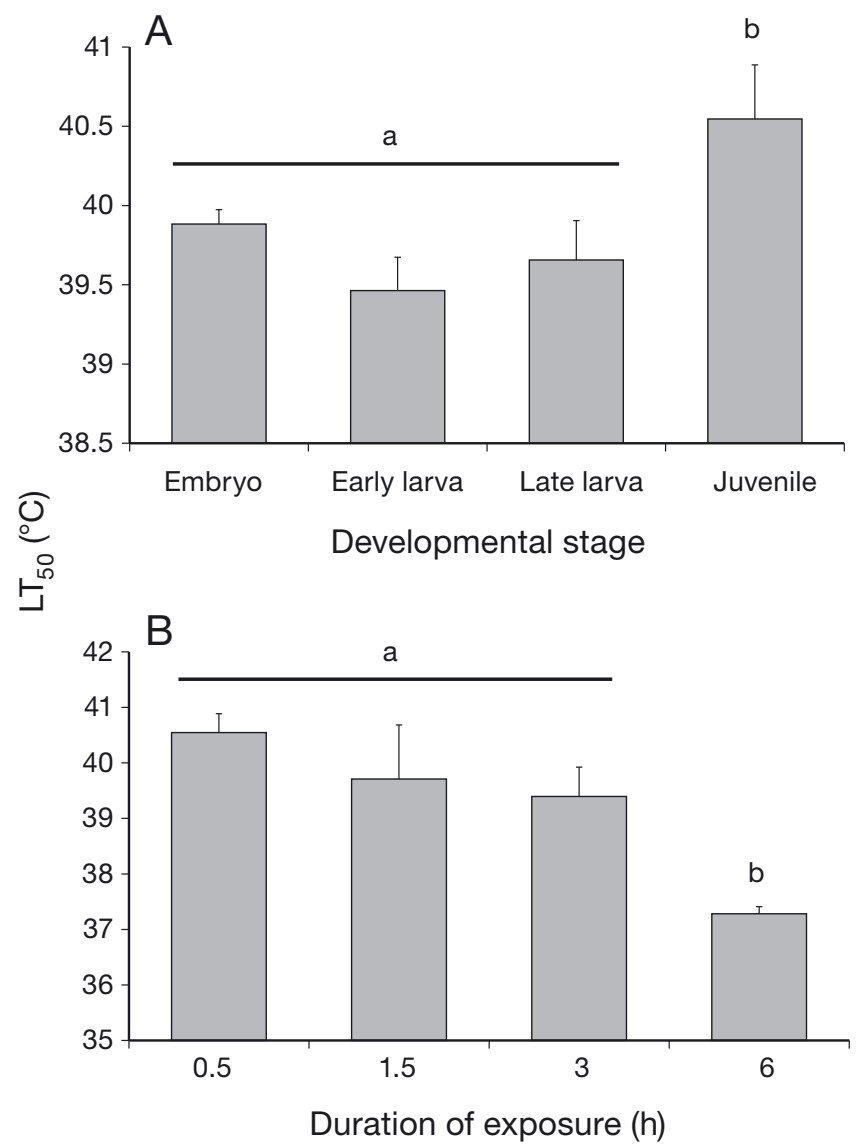

Fig. 2. Nematostella vectensis. Lethal temperatures $\left(\mathrm{LT}_{50}\right)$ for developmental stages and increasing durations for juvenile stage. Calculated $\mathrm{LT}_{50}$ values for 4 developmental stages and 4 exposure durations for juvenile polyps. Each experiment was with 12 ind. per temperature in a gradient from 37 to $43^{\circ} \mathrm{C}$ and replicated 4 times. (A) There was no significant difference in the $\mathrm{LT}_{50}$ among embryonic, early larval, and late larval stages, but juvenile stages had a significantly higher temperature tolerance. (B) The $\mathrm{LT}_{50}$ for juvenile polyps exposed to a temperature for $6.0 \mathrm{~h}$ was significantly lower than for the juvenile polyps exposed for $0.5,1.5 \mathrm{~h}$, or $3.0 \mathrm{~h}$. Data are mean $+1 \mathrm{SD}$. Letters indicate statistically different groups based on Tukey-Kramer post hoc tests

\section{Thermal tolerance of juveniles from different estuaries}

We compared temperature tolerance ( $\mathrm{LT}_{50}$ values) for 0.5 and $6.0 \mathrm{~h}$ exposure for juvenile offspring from adults collected at 3 geographic locations: Sippewissett, Massachusetts; Rhode River, Maryland; and Baruch, South Carolina. For the $0.5 \mathrm{~h}$ exposure, there was no significant difference in calculated $\mathrm{LT}_{50}$ values among the 3 populations $\left(F_{2,8}=1.42, \mathrm{p}=\right.$ 0.312). However, when juveniles were exposed to same temperature for $6.0 \mathrm{~h}$ there was a significant difference in $\mathrm{LT}_{50}$ among the 3 locations $\left(\mathrm{F}_{2,8}=29.42\right.$, $\mathrm{p}=0.0008$ ), with juveniles derived from the South Carolina population exhibiting an almost $2{ }^{\circ} \mathrm{C}$ higher $\mathrm{LT}_{50}$ compared with Massachusetts (Fig. 3).

\section{Growth rate versus body size, temperature, and clone line}

Common garden experiments measuring the growth rate of each clone line at 13,21 , or $29^{\circ} \mathrm{C}$ revealed significant effects of temperature, population (i.e. geographic origin), and the interaction of temperature and population (Table 2). No significant difference in growth rate was observed between clone lines generated from the same population.

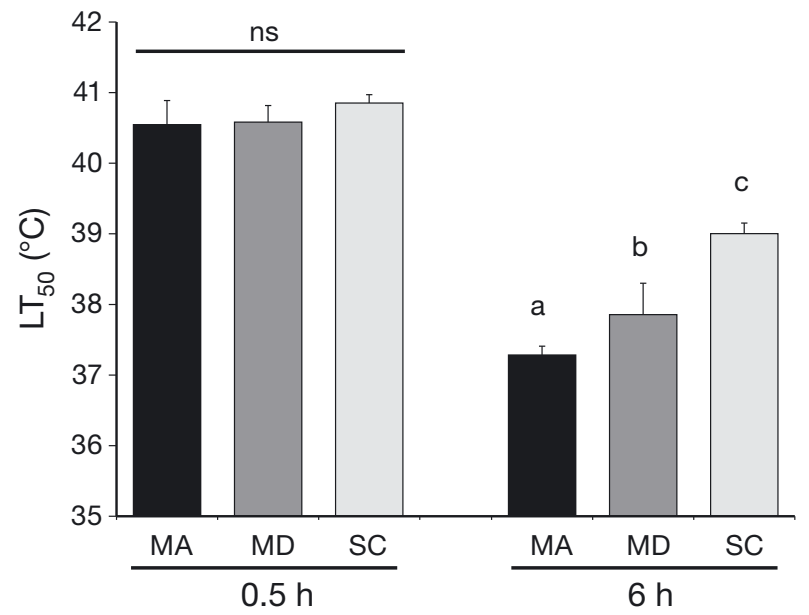

Fig. 3. Nematostella vectensis. Lethal temperature for juveniles from adults collected at 3 geographic locations along the Atlantic coast of the USA (see Table 1 for details). Each experiment consisted of 12 juveniles per temperature in a gradient from 37 to $43^{\circ} \mathrm{C}$ and replicated 4 times. While there was no significant difference in the $\mathrm{LT}_{50}$ for a $0.5 \mathrm{~h}$ exposure, significant differences among juveniles for a $6.0 \mathrm{~h}$ exposure were revealed. Data are mean $+1 \mathrm{SD}$. Letters indicate statistically different groups based on Tukey-Kramer post hoc tests (ns = no significant difference) 
Table 2. Nematostella vectensis. Effects of population (P) of origin, temperature $(\mathrm{T})$, the interaction of $\mathrm{P}$ and $\mathrm{T}$, and initial adult size on growth rate. The experiment was conducted over 4 wk. Both $\mathrm{P}$ and $\mathrm{T}$ significantly affected growth rate. In addition, the interaction of $\mathrm{P} \times \mathrm{T}$ was significant, indicating differential responses of populations to temperature

\begin{tabular}{|lrrrr|}
\hline Factor & df & MS & Fratio & p \\
\hline $\mathrm{P}$ & 9 & 137.938 & 33.6147 & $<0.001$ \\
$\mathrm{~T}$ & 2 & 876.735 & 213.6550 & $<0.001$ \\
$\mathrm{P} \times \mathrm{T}$ & 18 & 43.682 & 10.6451 & $<0.001$ \\
Initial size & 1 & 11.471 & 2.7160 & 0.101 \\
\hline
\end{tabular}

We observed substantial differences in the growth rate at particular temperatures between individuals collected from different geographic locations (Fig. 4). In all cases, growth rate was significantly different for each population (Table 3). For most, individuals had significantly highest growth rate at $21^{\circ} \mathrm{C}$ and lowest at $13^{\circ} \mathrm{C}$. The clone lines generated from a population collected from Kingsport, Nova Scotia, exhibited little growth over all temperatures. Individuals from Baruch, South Carolina, were unique in that they exhibited higher average growth at $29^{\circ} \mathrm{C}$ than at $21^{\circ} \mathrm{C}$, although these results were not statistically different. As most populations

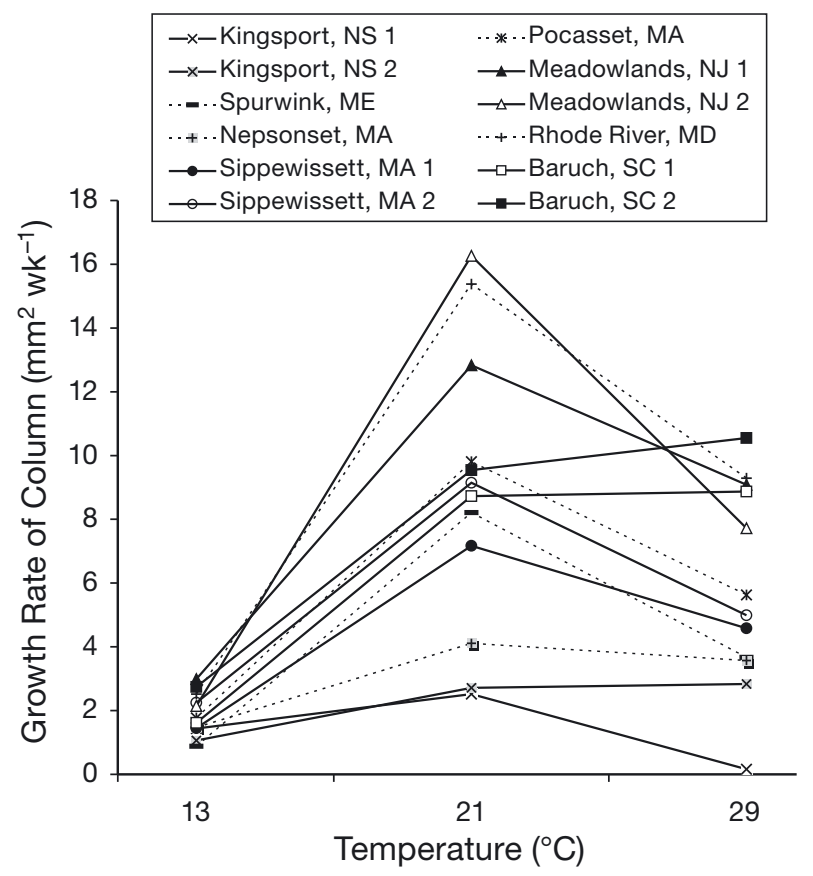

Fig. 4. Nematostella vectensis. Growth rate of column at 3 temperatures for 12 clone lines collected from 8 geographic locations (see Table 1 for details). Means from 5 ind. cultured independently at the respective temperature exhibited significantly higher growth at $21^{\circ} \mathrm{C}$ when compared with $29^{\circ} \mathrm{C}$, the results from the Baruch population were different from the general trend for these locations.

\section{Growth rate and latitude}

At $13^{\circ} \mathrm{C}$ and $21^{\circ} \mathrm{C}$, there was no significant relationship between growth rate and latitude (Fig. 5; $13^{\circ} \mathrm{C}: \mathrm{R}^{2}=0.140, \mathrm{p}=0.507 ; 21^{\circ} \mathrm{C}: \mathrm{R}^{2}=0.169, \mathrm{p}=$ 0.385 ). However, for individuals reared at $29^{\circ} \mathrm{C}$ there was a significant inverse relationship between growth rate and latitude $\left(\mathrm{R}^{2}=0.733, \mathrm{p}=0.0019\right)$ showing that individuals collected from higher latitudes grew slower at the highest temperature assayed.

\section{Regeneration time and rate}

We assessed the role of temperature, population, and their interaction on the timing (days to first tentacle emergence) and rate (tentacles per day) of regeneration. Time to regeneration, measured as days to first tentacle emergence, was only significantly related to rearing temperature with no significant effect of population, the interaction of population and temperature, or size (Table 4). Individuals began to regenerate tentacles within 1 or $2 \mathrm{~d}$ post-bisection at

Table 3. ANOVA statistics of growth rate for each population (see Table 1 for location details) at 3 different temperatures. In all cases, individuals had significantly different growth across temperatures. For the 4 populations where 2 clone lines were tested (Baruch, South Carolina; Meadowlands, New Jersey; Sippewissett, Massachusetts; and Kingsport, Nova Scotia) there was no significant difference between clones indicating a similar growth rate over the 3 temperatures. In a majority of populations, significantly highest growth rate was observed at $21^{\circ} \mathrm{C}$ and lowest at $13^{\circ} \mathrm{C}$ (see also Fig. 4)

\begin{tabular}{|lrrrr|}
\hline Population & df & \multicolumn{1}{c}{$F$} & p & Post hoc test \\
\hline Baruch, SC & 2,29 & 20.7600 & $<0.001$ & $13<21=29$ \\
Rhode River, MD & 2,14 & 12.3951 & 0.001 & $13<29<21$ \\
Meadowlands, NJ & 2,29 & 88.4251 & $<0.001$ & $13<29<21$ \\
Sippewissett, MA & 2,29 & 50.6402 & $<0.001$ & $13<29<21$ \\
Pocasset, MA & 2,14 & 51.2407 & $<0.001$ & $13<29<21$ \\
Neponset, MA & 2,14 & 20.9436 & $<0.001$ & $13<29=21$ \\
Spurwink, ME & 2,14 & 30.4697 & $<0.001$ & $13<29<21$ \\
Kingsport, NS & 2,29 & 3.7839 & 0.036 & $13 \leq 29 \leq 21$ \\
\hline
\end{tabular}




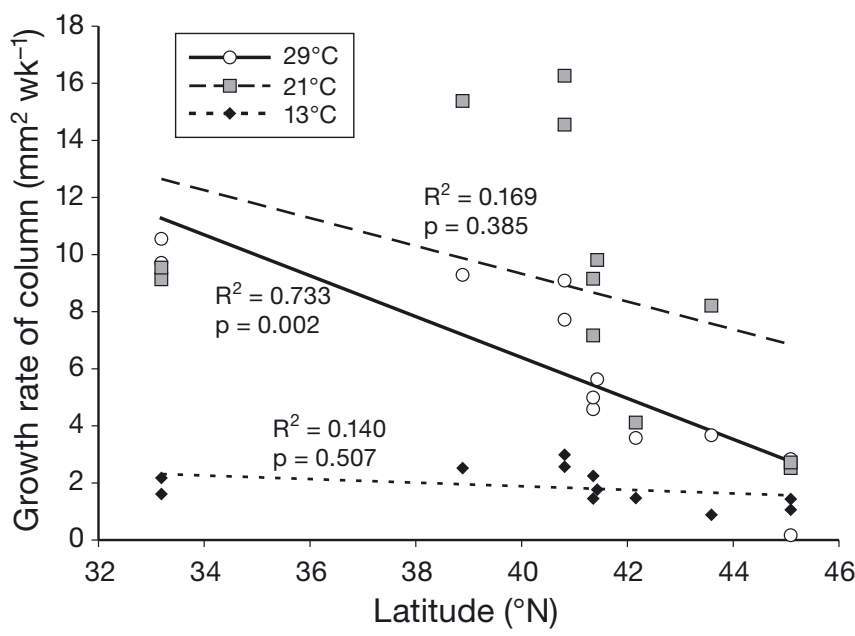

Fig. 5. Nematostella vectensis. Relationship between the latitude of origin and growth rate of column for the assayed clone lines at 3 temperatures $\left(13,21,29^{\circ} \mathrm{C}\right)$. There was no significant linear relationship of these 2 factors at $13^{\circ} \mathrm{C}$ or $21^{\circ} \mathrm{C}$ as determined by least squares regression. There was a significant, negative relationship between latitude and column growth rate for individuals cultured at $29^{\circ} \mathrm{C}$. Means from 5 ind. cultured independently at the respective temperature

$21^{\circ} \mathrm{C}$ and $29^{\circ} \mathrm{C}$ (Fig. 6A). However, at $13^{\circ} \mathrm{C}$, animals regenerated significantly more slowly, with no evidence of tentacle buds until 6 to $8 \mathrm{~d}$ after bisection.

Regeneration rate, measured as number of tentacles regenerated per day, was significantly related to temperature, population, and their interaction (Table 4). These relationships are evidenced for the $29^{\circ} \mathrm{C}$ treatment where there were large differences between clone lines (Fig. 6B, Appendix 1).

Table 4. Nematostella vectensis. Effects of population origin, temperature, the interaction of population and temperature, initial adult size before bisection, and initial size of regenerating fragment on (A) time and (B) rate of regeneration

\begin{tabular}{|lrrr|}
\hline Factor & df & Fratio & \multicolumn{1}{c|}{$\mathrm{p}$} \\
\hline (A) Regeneration time & & & \\
Population & 4 & 0.390 & 0.811 \\
Temperature & 2 & 19.150 & $<0.001$ \\
Population $\times$ Temperature & 8 & 0.690 & 0.717 \\
Adult size & 1 & 1.580 & 0.214 \\
Initial size & 1 & 0.029 & 0.866 \\
& & & \\
(B) Regeneration rate & & & \\
Population & 4 & 15.52 & $<0.001$ \\
Temperature & 2 & 196.62 & $<0.001$ \\
Population $\times$ Temperature & 8 & 9.67 & $<0.001$ \\
Adult size & 1 & 0.10 & 0.750 \\
Initial size & 1 & 0.42 & 0.517 \\
\hline
\end{tabular}
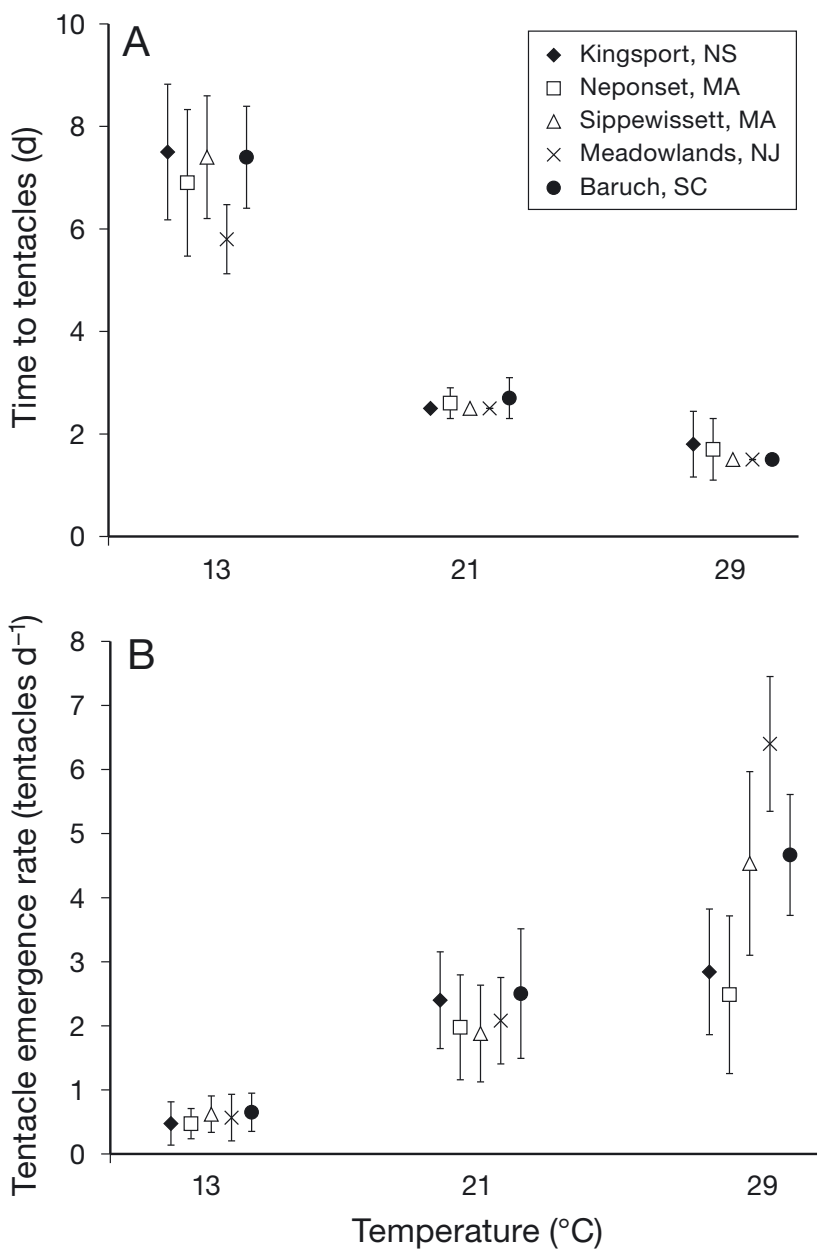

Fig. 6. Nematostella vectensis. Relationship of regeneration rate and temperature for clone lines from 5 locations along the Atlantic coast of North America (see Table 1 for details). (A) Temperature, but not clone line, was significantly related to time to tentacle emergence with regeneration of tentacles occurring earlier with increasing temperatures. (B) Tentacle emergence rate differed significantly among clone lines at the warmest temperature investigated $\left(29^{\circ} \mathrm{C}\right)$. The geographic origin of the clone line did not show a direct a latitudinal cline, but the 2 more northerly locations (Kingsport, Nova Scotia, and Neponset, Massachusetts) showed the lowest rate. Data are mean \pm 1 SD from 10 ind. cultured independently at the respective temperature

\section{DISCUSSION}

We measured multifarious roles that temperature exerts on the development, survival, growth, and regeneration of the starlet sea anemone Nematostella vectensis. By comparing adult growth and regeneration rates from field-isolated individuals collected from this species' broad coastal range, and the sensitivity of developmental stages to critical maximum temperatures, we identified multiple lines of 
evidence for a higher temperature tolerance in populations occupying lower latitudes. These results are the first evidence for the geographical structuring of significant phenotypic diversity in natural populations of this emerging model species.

In experiments to assess the temperature tolerance of Nematostella vectensis developmental stages, we measured a remarkably narrow temperature range $\left(\sim 1^{\circ} \mathrm{C}\right)$ where survival goes from 100 to $0 \%$. Embryonic and larval stages exhibited the same tolerance to temperature, which was significantly lower than the juvenile stage by $1^{\circ} \mathrm{C}$. These results suggest that there are no particularly vulnerable developmental stages, although the juveniles did have a slightly higher critical temperature. In this respect, $N$. vectensis seems to be similar to the sea urchins Echinometra lucunter and Strongylocentrotus purpuratus (Sewell \& Young 1999, Hammond \& Hofmann 2010) and molluscs Nucella spp. (Zippay \& Hofmann 2010), but it differs from a number of crab species that were found to have particularly sensitive stages (Sulkin \& McKeen 1994, Sanford et al. 2006).

In collecting temperature data from 1 field site occupied by Nematostella vectensis, we observed 4 times in the summer of 2008 where the recorded temperatures exceeded the calculated $\mathrm{LT}_{50}$ for all developmental stages. The temporal duration of these high-temperature events in July averaged almost $4 \mathrm{~h}$ (range from 175 to $300 \mathrm{~min}$ ). Thus, $N$. vectensis are living in environments very close to their thermal tolerance limits. With ongoing climate change, we expect that these estuaries will more regularly exceed the permissive temperatures for successful development for this anemone. Additionally, the anemones in these estuaries will experience longer exposures to high temperature, which can result in significantly increased mortality of juveniles.

Although the relative tolerance of developmental stages to temperature probably influences a species' distribution, physiological performance of adults occupying a broad range can be a signature for adaptation to local environments. Measurements comparing components of physiology over these large geographic scales, termed macrophysiology (Osovitz \& Hofmann 2007), have been reported for a variety of coastal species. Here, we report a large difference in growth rate for Nematostella vectensis adults originating from throughout its distribution along the Atlantic coast of North America. For the majority of the clone lines examined, the intermediate temperature $\left(21^{\circ} \mathrm{C}\right)$ resulted in the highest growth rate. Only Baruch, South Carolina, and Neponset, Massachusetts, exhibited statistically indistinguishable growth rates at $21^{\circ} \mathrm{C}$ and $29^{\circ} \mathrm{C}$, and only individuals from Baruch had higher mean growth rates at $29^{\circ} \mathrm{C}$. These data provide a first approximation for thermal performance curves in this species and set a range of temperatures that are amenable for positive growth rates in this species. Future experiments that measure growth rate at smaller intervals (e.g. $1^{\circ} \mathrm{C}$ ) would provide a detailed representation of the thermal performance curves for individuals from each location, which may resolve the temperature for peak growth.

Our data show a significant, negative relationship of growth rate and latitude for individuals cultured at $29^{\circ} \mathrm{C}$, but not $13^{\circ} \mathrm{C}$ or $21^{\circ} \mathrm{C}$. Similar relationships between physiological performance and thermal tolerance with latitude have been reported for other coastal species (Jansen et al. 2007, Zippay \& Hofmann 2010). Along any environmental gradient, genetically based variation in a phenotypic trait may (1) bear no consistent relationship to environmental variation in the trait, (2) positively reinforce environmental variation (cogradient variation), or (3) counteract environmental variation (countergradient variation). For $\mathrm{Ne}-$ matostella vectensis, these data suggest a signature of local adaptation to temperature similar to these previous studies reporting a negative relationship between temperature tolerance and latitude of origin.

We found no evidence of countergradient selection in Nematostella vectensis. Individuals from the Nova Scotia, the coolest part of $N$. vectensis' range, showed slow growth rates overall when compared with individuals from other portions of the range in all temperatures. Current data on the genetic diversity in this northern portion of $N$. vectensis' range does not support a hypothesis for populations in Nova Scotia containing reduced genetic diversity (Reitzel et al. 2008a, Sullivan et al. 2009, Reitzel et al. 2010). Thus, we have no evidence that our results could be explained by loss of genetic diversity due to these populations inhabiting the edge of the known geographic range. If countergradient selection had shaped growth or regeneration rates, we would expect the individuals from Kingsport, Nova Scotia, to exhibit higher growth in cooler temperatures when compared with individuals from lower latitude locations, which we did not observe.

Two common estuarine fishes, Fundulus heteroclitus and Menidia menidia, have both shown evidence for countergradient selection (Conover \& Present 1990, Schultz et al. 1996). In both of these species, individuals from northern populations grow significantly faster than individuals from southern populations at the same temperatures. Besides the taxonomic differences, Nematostella vectensis differs 
from these 2 species in at least 2 ecologically important ways, both of which may explain its divergent response. (1) N. vectensis is sedentary and occupies high marsh habitat, making individuals prone to larger variation in daily and seasonal temperature. Therefore, selection may have favored wide temperature tolerance in this species' history instead of faster growth. (2) There is no evidence that $N$. vectensis is a strict seasonal reproducer. As discussed by Lardies et al. (2004), countergradient selection is more likely to be observed in species with strict selection for reproduction at certain times of year, such as estuarine fishes and some insects.

Our work further supports the utility of a cnidarian species like Nematostella vectensis, where regeneration can be used to generate clonal lines to study the role of genotype in organismal performance (see also Shick \& Dowse 1985, Zamer et al. 1999) in evolutionary ecology and adds to this by measuring the regenerative process as a measure of organismal performance under varying environmental conditions. Our data on regeneration indicate subtle differences in this developmental process that reflect the roles of environmental temperature and population of origin. The simplest measure of regeneration rate that we employed - the time to the initial emergence of tentacles - was sufficient to reveal a significant difference between temperature treatments: in all clone lines assayed, the first appearance of tentacles differed by a factor $>3\left(1.5 \mathrm{~d}\right.$ at $29^{\circ} \mathrm{C}, 5.5 \mathrm{~d}$ at $\left.13^{\circ} \mathrm{C}\right)$. However, this simple measure failed to distinguish between clone lines subjected to the same temperature. By counting the average number of tentacles present for each clone line in each temperature, significant differences were readily apparent. For example, at $29^{\circ} \mathrm{C}$, the Meadowlands (New Jersey) individuals had a higher average number of tentacles than individuals from Kingsport, Nova Scotia, or Neponset, Massachusetts, at 1.5, 2.5, and $3.5 \mathrm{~d}$. This more detailed measure of regeneration rate also revealed an interaction between temperature and clone line. The same Meadowlands clone line that exhibited substantially more tentacles than Kingsport at $29^{\circ} \mathrm{C}$ on Day 2.5 showed no difference with Kingsport when compared at $21^{\circ} \mathrm{C}$.

There is good reason to expect that regeneration rate as a developmental process is maximized (Maginnis 2006) but limited by environmental variables, such as temperature (Henry \& Hart 2005). Delaying the regeneration of essential structures, such as tentacles, can impair critical organismal functions, such as feeding or predator defense. In turn, this could lead to a substantial reduction in fitness that out- weighs the immediate costs of regeneration (Maginnis 2006). Therefore, evolving developmental mechanisms that maximize the rate of regeneration may be selected in all populations.

Our results show the initial size of the adult or the size of the regenerating fragment did not significantly affect the rate of regeneration, suggesting that energy reserves played little to no role in the timing or success of regeneration. Previous work in cnidarians has also shown size-independent regeneration rates in a cnidarian (Wahle 1983). Conversely, other work with cnidarians has shown that larger fragments regenerate more quickly and more successfully than smaller fragments (Karlson 1988, Lasker 1990).

The clearest evidence we found for a difference among clone lines in their temperature-specific regeneration rates were the data on tentacle number. The relationship of this phenotypic variance to fitness is difficult to discern without additional experimental data. Tentacle length may be as important, or even more important, than tentacle number with respect to the animal's ability to feed, and this may vary depending on the type of prey. Nematostella vectensis feeds on both planktonic prey (e.g. crustacean nauplii) and infaunal prey (e.g. burrowing oligochaetes, chironomid larvae) (Frank \& Bleakney 1978). Therefore, long tentacles would allow a partially buried anemone to extract swimming prey from a larger hemisphere of water better than a counterpart with a great number of shorter tentacles. To better understand the fitness consequences of the observed differences in tentacle regeneration rates, future studies should specifically examine variance in tentacle length and feeding ability on various prey types over the course of regeneration.

Our data on regeneration rate may reflect a wellknown genetic and phenotypic break that occurs at Cape Cod, Massachusetts (Wares 2002). Cape Cod represents a transitional boundary between warmand cold-water regions that acts as a zoogeographic boundary (Allee 1923). Interestingly, at $29^{\circ} \mathrm{C}$, the more slowly regenerating clones originate north of Cape Cod (Neponset and Kingsport) and the more rapidly regenerating clones are from populations to the south (Sippewissett, Meadowlands, and Baruch). More thorough sampling on either side of this known zoogeographic boundary will be needed to determine if there is a definitive phenotypic break between Nematostella vectensis populations located north and south of Cape Cod.

The observed differences in growth and regeneration rate among populations of Nematostella vectensis suggest future research to characterize the molec- 
ular mechanisms responsible for the observed variation. Because our data are consistent with temperature tolerance, study of heat shock proteins (HSPs) would be particularly informative. HSPs have been intensively studied in various organisms, including many marine species, where their expression correlates closely with stress-inducing temperatures (Feder \& Hofmann 1999, Hofmann et al. 2002). Additionally, in a few cases, there is a strong correlation between HSP expression and latitude in various marine species (Osovitz \& Hofmann 2005, Henkel \& Hofmann 2008, Hammond \& Hofmann 2010). HSPs from various cnidarians have been studied in a variety of stress responses including temperature (Bosch et al. 1988, Black et al. 1995, Hayes \& King 1995, Kingsley et al. 2003), as well as coral bleaching (Downs et al. 2002) and aggression (Rossi \& Snyder 2001). N. vectensis contains numerous HSPs (Reitzel et al. $2008 b$ ) that may prove to be good initial targets for assessing differences in temperature tolerance over development and geography.

\section{CONCLUSION}

Nematostella vectensis has a wide geographic distribution throughout estuaries, primarily along coastal North America. Across this range, environmental variables, particularly temperature, range dramatically and probably exert selection for local adaptation. Previous work has shown that populations have limited gene flow, which would tend to promote local adaptation. Here, we have shown that $N$. vectensis has sharp windows for temperature tolerance, small differences in critical temperature maxima over developmental stages, and growth and regeneration rates that show effects of both temperature and geography. Future studies addressing molecular mechanisms underlying the sensitivity and physiological performance will help understand the mechanisms of local adaptation to variation in environmental temperature.

Acknowledgements. We thank J. Darling and J. Sullivan for assisting in the collection of anemones used in this study, as well as contributing ideas towards experimental design and statistical analysis. T.C. and S.E. were both supported by the Undergraduate Research Opportunities Program (UROP) at Boston University. A.M.R. was supported by EPA STAR Fellowship F5E11155 to A.M.R. and J.R.F. and the Beacon Institute for Rivers and Estuaries to A.M.R. A.M.T. was supported by MCB-1057354 from the National Science Foundation. We also thank J. M. Shick and 2 anonymous reviewers for their insightful comments that greatly improved this manuscript.

\section{LITERATURE CITED}

Allee WC (1923) Studies in marine ecology: IV. The effect of temperature in limiting the geographic range of invertebrates of the Woods Hole littoral. Ecology 4:341-354

Arai MN (1997) A functional biology of Scyphozoa. Chapman \& Hall, London

Bilton DT, Paula J, Bishop JDD (2002) Dispersal, genetic differentiation and speciation in estuarine organisms. Est Coast Shelf Sci 55:937-952

Black NA, Voellmy R, Szmant AM (1995) Heat shock protein induction in Montastraea faveolata and Aiptasia pallida exposed to elevated temperatures. Biol Bull 188: 234-240

> Bosch TC, Krylow SM, Bode HR, Steele RE (1988) Temperature tolerance and synthesis of heat shock proteins: these responses are present in Hydra attenuata but absent in Hydra oligactis. Proc Natl Acad Sci 85:7927-7931

Braby CE, Somero GN (2006) Following the heart: temperature and salinity effects on heart rate in native and invasive species of blue mussels (genus Mytilus). J Exp Biol 209:2554-2566

Carpenter KE, Abrar M, Aeby G, Aronson RB and others (2008) One-third of reef-building corals face elevated extinction risk from climate change and local impacts. Science 321:560-563

Conover DO, Present TMC (1990) Countergradient variation in growth rate: compensation for length of the growing season among Atlantic silversides from different latitudes. Oecologia 83:316-324

Crawford DL, Powers DA (1989) Molecular basis of evolutionary adaptation at the lactate dehydrogenase-B locus in the fish Fundulus heteroclitus. PNAS 86:9365-9369

Császár NBM, Ralph PJ, Frankham R, Berkelmans R, van Oppen MJH (2010) Estimating the potential for adaptation of corals to climate warming. PLoS ONE 5:e9751

Darling JA, Reitzel AM, Finnerty JR (2004) Regional population structure of a widely introduced estuarine invertebrate: Nematostella vectensis Stephenson in New England. Mol Ecol 13:2969-2981

> Darling JA, Kuenzi A, Reitzel AM (2009) Human-mediated transport determines the non-native distribution of the anemone Nematostella vectensis, a dispersal-limited estuarine invertebrate. Mar Ecol Prog Ser 380:137-146

> Doney SC, Ruckelshaus M, Duffy JE, Barry JP and others (2012) Climate change impacts on marine ecosystems. Annu Rev Mar Sci 4:11-37

> Downs CA, Fauth JE, Halas JC, Dustan P, Bemiss J, Woodley CM (2002) Oxidative stress and seasonal coral bleaching. Free Radic Biol Med 33:533-543

> Fangue NA, Hofmeister M, Schulte PM (2006) Intraspecific variation in thermal tolerance and heat shock protein gene expression in common killifish, Fundulus heteroclitus. J Exp Biol 209:2859-2872

- Feder ME, Hofmann GE (1999) Heat-shock proteins, molecular chaperones, and the stress response: evolutionary and ecological physiology. Annu Rev Physiol 61:243-282

Frank PG, Bleakney JS (1978) Asexual reproduction, diet, and anomalies of the anemone Nematostella vectensis in Nova Scotia. Can Field-Nat 92:259-263

$>$ Garant D, Forde SE, Hendry AP (2007) The multifarious effects of dispersal and gene flow on contemporary adaptation. Funct Ecol 21:434-443

> Hammond L, Hofmann G (2010) Thermal tolerance of Strongylocentrotus purpuratus early life history stages: 
mortality, stress-induced gene expression and biogeographic patterns. Mar Biol 157:2677-2687

Hand C, Uhlinger KR (1992) The culture, sexual and asexual reproduction, and growth of the sea anemone Nematostella vectensis. Biol Bull 182:169-176

Hand C, Uhlinger K (1994) The unique, widely distributed sea anemone, Nematostella vectensis Stephenson: a review, new facts, and questions. Estuaries 17:501-508

Hand C, Uhlinger KR (1995) Asexual reproduction by transverse fission and some anomalies in the sea anemone Nematostella vectensis. Invertebr Biol 114:9-18

Harley CDG, Randall Hughes A, Hultgren KM, Miner BG and others (2006) The impacts of climate change in coastal marine systems. Ecol Lett 9:228-241

> Hayes RL, King CM (1995) Induction of 70-kD heat shock protein in scleractinian corals by elevated temperature: significance for coral bleaching. Mol Mar Biol Biotechnol 4:36-42

> Helmuth B, Harley CDG, Halpin PM, O'Donnell M, Hofmann GE, Blanchette CA (2002) Climate change and latitudinal patterns of intertidal thermal stress. Science 298: 1015-1017

> Henkel SK, Hofmann GE (2008) Differing patterns of hsp70 gene expression in invasive and native kelp species: evidence for acclimation-induced variation. J Appl Phycol 20:915-924

> Henry L, Hart MW (2005) Regeneration from injury and resource allocation in sponges and corals - a review. Int Rev Hydrobiol 90:125-158

Hochachka PW, Somero GN (2002) Biochemical adaptation: mechanism and process in physiological evolution. Oxford University Press, New York, NY

> Hoffmann AA, Sgro CM (2011) Climate change and evolutionary adaptation. Nature 470:479-485

> Hofmann GE, Buckley BA, Place SP, Zippay ML (2002) Molecular chaperones in ectothermic intertidal animals: biochemical function and gene expression. Integr Comp Biol 42:808-814

Jansen JM, Pronker A, Kube S, Sokolowski A and others (2007) Geographic and seasonal patterns and limits on the adaptive response to temperature of European Mytilus spp. and Macoma balthica populations. Oecologia 154:23-34

Jentsch A, Kreyling J, Beierkuhnlein C (2007) A new generation of climate-change experiments: events, not trends. Front Ecol Environ 5:365-374

Karlson RH (1988) Size-dependent growth in two zoanthid species: a contrast in clonal strategies. Ecology 69: 1219-1232

Kawecki TJ, Ebert D (2004) Conceptual issues in local adaptation. Ecol Lett 7:1225-1241

Kennish MJ (2002) Environmental threats and environmental future of estuaries. Environ Conserv 29:78-107

Kingsley RJ, Afif E, Cox BC, Kothari S and others (2003) Expression of heat shock and cold shock proteins in the gorgonian Leptogorgia virgulata. J Exp Zool A 296A: 98-107

Lardies MA, Bacigalupe LD, Bozinovic F (2004) Testing the metabolic cold adaptation hypothesis: an intraspecific latitudinal comparison in the common woodlouse. Evol Ecol Res 6:567-578

Lasker HR (1990) Clonal propagation and population dynamics of a gorgonian coral. Ecology 71:1578-1589

Lima FP, Wethey DS (2012) Three decades of high-resolution coastal sea surface temperatures reveal more than warming. Nature Commun 3:704

> Maginnis TL (2006) The costs of autotomy and regeneration in animals: a review and framework for future research. Behav Ecol 17:857-872

Magness DR, Morton JM, Huettmann F, Chapin FS, McGuire AD (2011) A climate-change adaptation framework to reduce continental-scale vulnerability across conservation reserves. Ecosphere 2:112

Mayer AG (1914) The effects of temperature upon tropical marine animals. Pap Tort Lab 6:1-24

McDonald KA, Brown JH (1992) Using montane mammals to model extinctions due to global change. Conserv Biol 6: 409-415

> Meyer E, Davies S, Wang S, Willis BL, Abrego D, Juenger TE, Matz MV (2009) Genetic variation in responses to a settlement cue and elevated temperature in the reefbuilding coral Acropora millepora. Mar Ecol Prog Ser 392:81-92

Osovitz CJ, Hofmann GE (2005) Thermal-history dependent expression of the $h s p 70$ gene in the purple sea urchins: biogeographic patterns and the effect of thermal acclimation. J Exp Mar Biol Ecol 327:134-143

> Osovitz CJ, Hofmann GE (2007) Marine macrophysiology: studying physiological variation across large spatial scales in marine systems. Comp Biochem Physiol A 147: 821-827

Parmesan C (2006) Ecological and evolutionary responses to recent climate change. Annu Rev Ecol Evol Syst 37: 637-669

Pennings SC, Bertness MD (2001) Salt marsh communities. In: Bertness MD, Gaines SD, Hay M (eds) Marine community ecology. Sinauer Associates, Sunderland, MA

> Pörtner HO (2002) Climate variations and the physiological basis of temperature dependent biogeography: systemic to molecular hierarchy of thermal tolerance in animals. Comp Biochem Physiol A 132:739-761

Pörtner HO, Berdal B, Blust R, Brix O and others (2001) Climate induced temperature effects on growth performance, fecundity and recruitment in marine fish: developing a hypothesis for cause and effect relationships in Atlantic cod (Gadus morhua) and common eelpout (Zoarces viviparus). Cont Shelf Res 21:1975-1997

> Powers DA, Lauerman T, Crawford D, DiMichele L (1991) Genetic mechanisms for adapting to a changing environment. Annu Rev Genet 25:629-660

> Reitzel AM, Burton PM, Krone C, Finnerty JR (2007) Comparison of developmental trajectories in the starlet sea anemone Nematostella vectensis: embryogenesis, regeneration, and two forms of asexual fission. Invertebr Biol 126:99-112

> Reitzel AM, Darling JA, Sullivan JC, Finnerty JR (2008a) Global population genetic structure of the starlet anemone Nematostella vectensis: multiple introductions and implications for conservation policy. Biol Inv 10: 1197-1213

> Reitzel AM, Sullivan JC, Traylor-Knowles N, Finnerty JR (2008b) Genomic survey of candidate stress-response genes in the estuarine anemone Nematostella vectensis. Biol Bull 214:233-254

> Reitzel AM, Sullivan JC, Finnerty JR (2010) Discovering SNPs in protein coding regions with StellaSNP: illustrating the characterization and geographic distribution of polymorphisms in the estuarine anemone Nematostella vectensis. Est Coasts 33:930-943

Rossi S, Snyder MJ (2001) Competition for space among ses- 
sile marine invertebrates: changes in hsp70 expression in two pacific cnidarians. Biol Bull 201:385-393

Ruff CP, Schindler DE, Armstrong JB, Bentley KT and others (2011) Temperature-associated population diversity in salmon confers benefits to mobile consumers. Ecology 92:2073-2084

Sanford E, Holzman SB, Haney RA, Rand DM, Bertness MD (2006) Larval tolerance, gene flow, and the northern geographic range limit of fiddler crabs. Ecology 87: 2882-2894

Schulte PM, Healy TM, Fangue NA (2011) Thermal performance curves, phenotypic plasticity, and the time scales of temperature exposure. Integr Comp Biol 51: 691-702

Schultz ET, Reynolds KE, Conover DO (1996) Countergradient variation in growth among newly hatched Fundulus heteroclitus: geographic differences revealed by common-environment experiments. Funct Ecol 10:366-374

Sewell MA, Young CM (1999) Temperature limits to fertilization and early development in the tropical sea urchin Echinometra lucunter. J Exp Mar Biol Ecol 236:291-305

Shick JM (1991) A functional biology of aea anemones. Chapman and Hall, London

Shick JM, Dowse HB (1985) Genetic basis of physiological variation in natural populations of sea anemones: intraand interclonal analyses of variance. In: Gibbs PE (ed) Proc 19th Eur Mar Biol Symp Plymouth, Sep 16-21, 1984. Cambridge University Press, Cambridge, p 465-179

Shick JM, Hoffmann RJ, Lamb AN (1979) Asexual reproduction, population structure, and genotype-environment interactions in sea anemones. Am Zool 19:699-713

Solomon S, Qin D, Manning M, Chen Z and others (eds) (2007) Contribution of Working Group I to the Fourth Assessment Report of the Intergovernmental Panel on Climate Change, 2007. Cambridge University Press, Cambridge

Somero GN (2011) Comparative physiology: a 'crystal ball' for predicting consequences of global change. Am J Physiol Regul Integr Comp Physiol 301:R1-R14

Somero GN (2012) The physiology of global change: linking patterns to mechanisms. Annu Rev Mar Sci 4:39-61

Stillman J, Somero G (1996) Adaptation to temperature stress and aerial exposure in congeneric species of intertidal porcelain crabs (genus Petrolisthes): correlation of physiology, biochemistry and morphology with vertical distribution. J Exp Biol 199:1845-1855

> Stillman JH, Somero GN (2000) A comparative analysis of the upper thermal tolerance limits of Eastern Pacific porcelain crabs, genus Petrolisthes: influences of latitude, vertical zonation, acclimation, and phylogeny. Physiol Biochem Zool 73:200-208

Sulkin SD, McKeen G (1994) Influence of temperature on larval development of four co-occurring species of the brachyuran genus Cancer. Mar Biol 118:593-600

> Sullivan JC, Wolenski FS, Reitzel AM, French CE, TraylorKnowles N, Gilmore TD, Finnerty JR (2009) Two alleles of NF- B in the sea anemone Nematostella vectensis are widely dispersed in nature and encode proteins with distinct activities. PLoS ONE 4:e7311

Sunday JM, Bates AE, Dulvy NK (2011) Global analysis of thermal tolerance and latitude in ectotherms. Proc Biol Sci 278:1823-1830

> Tomanek L (2008) The importance of physiological limits in determining biogeographical range shifts due to global climate change: the heat-shock response. Physiol Biochem Zool 81:709-717

> Vernberg FJ (1962) Comparative physiology: latitudinal effects on physiological properties of animal populations. Annu Rev Physiol 24:517-546

> Visser ME (2008) Keeping up with a warming world; assessing the rate of adaptation to climate change. Proc Biol Sci 275:649-659

> Wahle CM (1983) Regeneration of injuries among Jamaican gorgonians: the roles of colony physiology and environment. Biol Bull 165:778-790

> Wares JP (2002) Community genetics in the northwestern Atlantic intertidal. Mol Ecol 11:1131-1144

- Warner RR (1997) Evolutionary ecology: how to reconcile pelagic dispersal with local adaptation. Coral Reefs 16: S115-S120

> Xenopoulos MA, Lodge DM, Alcamo J, Märker M, Schulze K, Van Vuuren DP (2005) Scenarios of freshwater fish extinctions from climate change and water withdrawal. Global Change Biol 11:1557-1564

Zamer WE, McManus MG, Rowell CB (1999) Physiological variation in clonal anemones: energy balance and quantitative genetics. Am Zool 39:412-421

- Zippay M, Hofmann G (2010) Physiological tolerances across latitudes: thermal sensitivity of larval marine snails (Nucella spp.). Mar Biol 157:707-714 

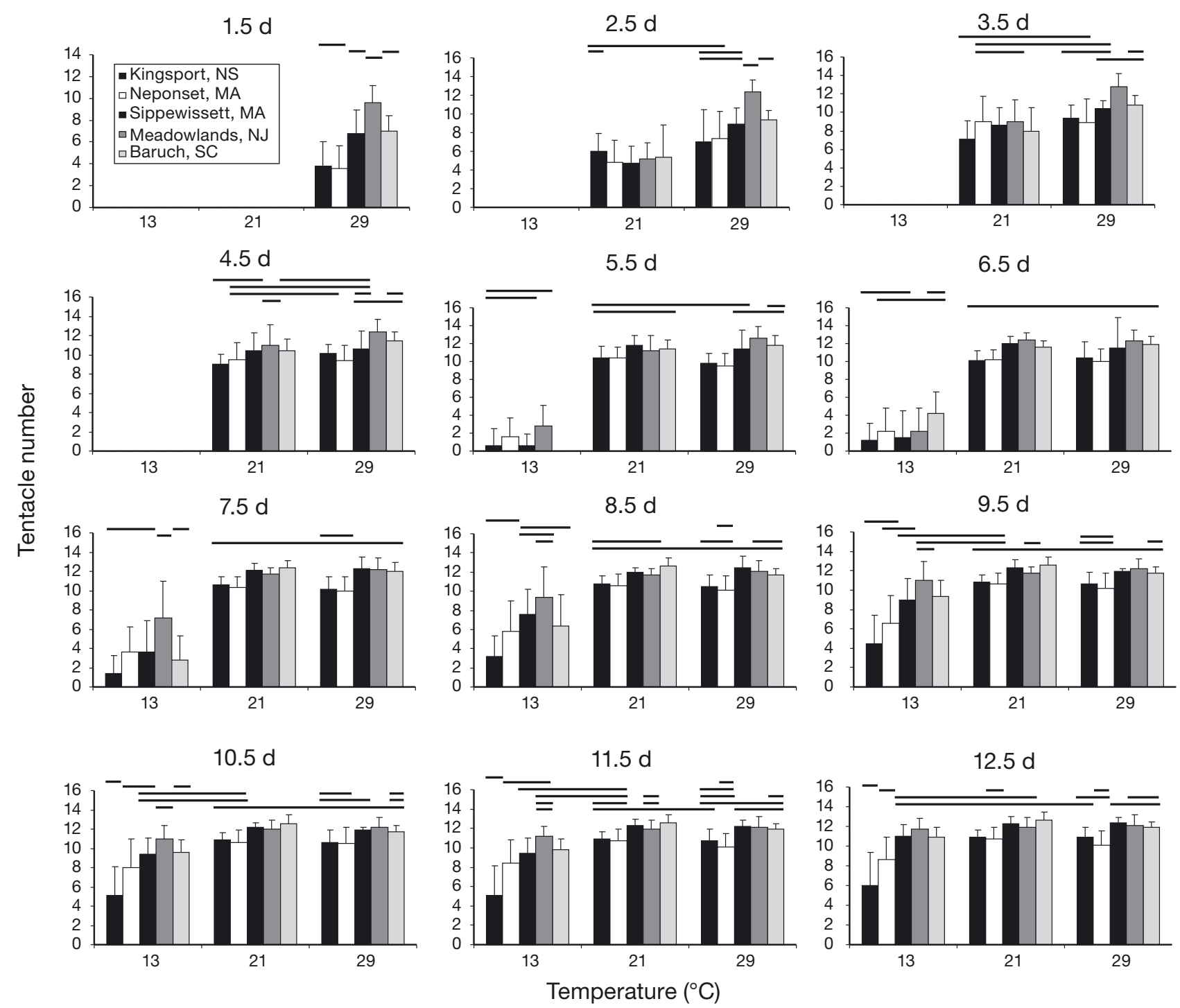

Appendix 1. Nematostella vectensis. Temporal relationship of tentacle number (mean $+1 \mathrm{SD}$ ) for 10 ind. from 5 clonal lines cultured in 3 temperatures. Daily observations showed significant differences in the number and emergence rate of tentacles among clone lines. All clone lines developed tentacles $1.5 \mathrm{~d}$ after bisection when cultured at $29^{\circ} \mathrm{C}$ and $2.5 \mathrm{~d}$ at $21^{\circ} \mathrm{C}$. Tentacle regeneration was significantly slower at $13^{\circ} \mathrm{C}$ as well as a lower number of tentacles at emergence when compared with the other temperatures. By $12.5 \mathrm{~d}$ post-bisection, most clone lines had developed a similar number of tentacles in all 3 temperature treatments, with the exception of Kingsport, Nova Scotia, which had fewer tentacles than other clone lines at $13^{\circ} \mathrm{C}$. A horizontal line at the same height above 2 columns indicates that the treatments are not statistically distinguishable from each other. For example, in the upper left panel, at $29^{\circ} \mathrm{C}$, Kingsport is not distinguishable from Neponset but both are distinguishable from Meadowlands

Editorial responsibility: Hans Heinrich Janssen, Oldendorf/Luhe, Germany
Submitted: January 26, 2012; Accepted: January 23, 2013 Proofs received from author(s): June 4, 2013 